\section{カルバペネム系抗生物質のバルプ 口酸吸収阻害作用機序}

\begin{tabular}{|c|c|c|}
\hline 鳥井真由美 ${ }^{* 1, * 2}$ & 泉美也子 ${ }^{* 1, * 2}$ & 森川 歩*1 \\
\hline 土屋浩一郎"1 & 滝口祥令"1 & \\
\hline
\end{tabular}

【目的】

バルプロ酸（VPA）投与患者において、カルバペネム 系抗生物質の併用投与により血中VPA濃度が低下するこ とから、両薬剤の併用は禁忌となっている。しかし、本薬 物間相互作用の機序についてはまだ十分に解明されていな い。我々はこれまでに本薬物間相互作用はカルバペネム系 抗生物質によるVPAの吸収阻害によることを報告した ${ }^{21}$ 。 今回、カルバペネム系抗生物質によるVPA吸収阻害作用 の機序を明らかにする目的で、腸上皮細胞薬物輸送実験モ デルである培養ヒトCaco-2細胞単層膜を用いて、カルバ ペネム系抗生物質によるVPA吸収阻害作用を各種輸送担 体阻害薬の作用と比較検討した。

\section{【方法】}

Transwellのculture insert膜上に培養 Caco-2 細胞単首 膜を定法に従い作製し、TEER500 $\Omega \mathrm{cm}^{2}$ 以上を実験に用 いた。 pH勾配（apical側 pH6.0、basolateral側 pH7.4） and/or 重炭酸勾配 (apical側 $0 \mathrm{mM}$ 、 basolateral側 $25 \mathrm{mM})$ 下、経細胞輸送実験では ${ }^{14}[\mathrm{C}]-\mathrm{VPA}(10 \mu \mathrm{M})$ を apical側または basolateral側に添加し、 $37^{\circ} \mathrm{C} 、 60$ 分間 incubate後 、 apical側 $\rightarrow$ basolateral側または basolateral 側 $\rightarrow$ apical側へ透過されたVPA量を求めた。また、細胞内 取り込み実験では、apical側にVPAを添加し 3 分間後、細 胞内VPA量を求めた。各種阻害薬は apical側および basolateral側両方に添加し、15分間前処置した。また paracellular markerとしで[$[\mathrm{H}]$-mannitol $(1 \mathrm{nM})$ を用い た。

\section{【結果】}

VPAのapical側 $\rightarrow$ basolateral側への経細胞輸送（吸収） はpH勾配存在下で促進され、透過量はVPA添加濃度に依 存して増加し、飽和がみられ、また、代謝阻害薬 2,4dinitrophenol (DNP; $1 \mathrm{mM}$ ) で阻害された。カルバペネム 系抗生物質 imipenem (IPM)、 panipenem (PAPM)、 meropenem (MEPM)、 biapenem (BIPM) はいずれも 0.01-10mMで濃度依存的にVPA透過を阻害し、その作用

\footnotetext{
*1 徳島大学大学院薬学研究科臨床薬理学 干770-8505 德島市庄町1-78

*2 徳島大学附属病院薬骫部
}

はbasolateral側にのみ各抗生物質を添加した場合でも同様 に認められた。しかし、apical側にのみ添加した場合、 MEPMを除いてVPA透過阻害はみられなかった。 Monocarboxylic acid transporter (MCT) 阻害薬 lactic acid (1mM) および選択的MCT1阻害薬 p-chloromercuri benzensulfonate $(5 \mathrm{mM})$, anion exchager 阻害薬 4,4'diidothiocyanostilbene-4,4'-disulfonate (DIDS;2mM) は、それぞれbasolateral側にのみ添加した場合でもVPA 透過を阻害したが、apical側にのみ添加した場合では、 MCT阻害薬は阻害を示したが、DIDSは影響がみられなかっ た。VPAのapical側からの細胞内取り込みは、MCT阻害 薬、MEPMにより阻害されたが、IPM、PAPM、BIPM、 DIDSでは阻害されなかった。VPAの経細胞輸送は重炭酸 勾配のみ（pH勾配なし）では促進はみられず、各抗生物 質、DIDSによる透過阻害もみられなかった。

一方、basolateral側 $\rightarrow$ apical側へのVPAの経細胞透過量 はDNP、MEPM処置により増加したが、IPM、PAPM、 BIPMおよびDIDS処置では、影響はみられなかった。

\section{【考察】}

Caco-2細胞におけるVPAの経細胞輸送に及ぼすカルバ ペネム系抗生物質の影響はDIDSと類似しており、 basolateral側でのH $\mathrm{H}^{+}$にcouple したVPAのeffluxを阻害す ることにより、apical側 $\rightarrow$ basolateral側へのVPA輸送を阻 害していると思われる。重炭酸勾配のみではVPAの吸収 は促進されず、DIDSも阻害作用を示さなかったことから、 basolateral側でのVPA輸送にはanion exchangerの関与 はなく、その他の輸送機序が存在している可能性が示唆さ れた。また、MEPMはapical側でのVPAのinfluxも阻害す ることが明らかとなった。

以上の結果より、カルバペネム系抗生物質は、 $\mathrm{pH}$ 勾配 存在下、DIDS同様、小腸上皮細胞基底膜におけるVPAの 輸送経路を阻害することにより、VPAの吸収阻害作用を 示すことが示唆された。

\section{【文献】}

1.M.Torii, Y.Takiguchi, F.Saito, M.Izumi, M.Yokota. Inhibition by carbapenem antibiotic imipenem of intestinal absorption of valproic acid in rats. J.Pharm. Pharmacol. 53:823-829, 2001.

2.M.Torii, Y.Takiguchi, M.Izumi, T.Fukushima, M. Yokota. Carbapenem antibiotics inhibit valproic acid transport in Caco- 2 cell monolayers. Int.J.Pharm. 233:253-256, 2002. 